\title{
Adoption of Treasury Single Account (TSA) by State Governments of Nigeria: Benefits, Challenges and Prospects
}

\author{
Ekubiat John Udo ${ }^{1,}$, , Ime Edet Esara ${ }^{2}$ \\ ${ }^{1}$ Department of Accountancy, Akwa Ibom State Polytechnic, Ikot Osurua, Ikot Ekpene, Nigeria \\ ${ }^{2}$ Department of Banking \& Finance, Akwa Ibom State Polytechnic, Ikot Osurua, Ikot Ekpene, Nigeria
}

Email address:

ekujohn@yahoo.com (E. J. Udo), imeesara@yahoo.com (I. E. Esara)

\section{To cite this article:}

Ekubiat John Udo, Ime Edet Esara. Adoption of Treasury Single Account (TSA) by State Governments of Nigeria: Benefits, Challenges and Prospects. Journal of Finance and Accounting. Vol. 4, No. 3, 2016, pp. 126-130. doi: 10.11648/j.jfa.20160403.14

Received: May 2,2016; Accepted: May 7, 2016; Published: May 17, 2016

\begin{abstract}
Nigeria's Public Funds at all levels have been wrongly accounted-for by previous administrations. But to avert this threat coupled with the present country's dwindling economy, Federal Government of Nigeria has implemented Treasury Single Account (TSA) to properly manage the scare financial resources but State Governments of Nigeria have been left-out. The aim of this study was to examine the benefits, challenges and prospects of adoption of Treasury Single Account (TSA) by State Governments of Nigeria. Descriptive cross-sectional survey design was adopted for the study. The population for the study consisted of 200 Professional Accountants in Akwa Ibom State. Taro Yamane's statistical formula was used to select sample size of 133. Purposive sampling technique was used to select the 133 respondents/samples. The data obtained from questionnaire administration were analyzed using descriptive statistics and t-test statistics. The finding reveals that, TSA adoption and full implementation by the state governments will be of greatest benefit as showed in the weighted means scores of 4.20 and $t_{\text {cal }}$ of 24.87; there will be challenges in a short-run but the benefits at a long-run will definitely out-weight the challenges. It is the conclusion in this study that, State Governments of Nigeria should adopt and fully implement TSA for successful control and accountability of public funds so as to avoid bailout funds always from any source. State governments should enlighten all stakeholders on the benefits of TSA adoption as well as professional and regulatory bodies (ICAN, CBN, IMF, etc.) should help in designing, conceptualizing and road-mapping of TSA for the states.
\end{abstract}

Keywords: Treasury Single Account (TSA), State Governments of Nigeria, Adoption, Benefits, Challenges, Prospects, Public Funds, MDAs

\section{Introduction}

The adoption and full implementation of Treasury Single Account (TSA) by any government, especially in a dwindling economy cannot be over-emphasized. This is due to the fact that a Treasury Single Account is primarily to ensure accountability of government revenue, enhance transparency and avoid misappropriation of public funds. [1] opined that the maintenance of a Treasury Single Account helps to ensure proper cash management by eliminating idle funds usually left with different deposit money banks and in a way enhance reconciliation of revenue collection and payment. According to [2], TSA is an essential tool for consolidating and managing governments' cash resources, thus minimizing borrowing cost.

According to S. 80 (1) of the [3] "all revenues, or other monies raised or received by the Federation (not being revenues or other monies payable under this said constitution or any Act of the National Assembly into any other public fund of the federation established for a specific purpose) shall be paid into and from one Consolidated Revenue Fund of the Federation". However, successive governments of Nigeria have continued to operate multiple accounts for the collection and disbursing of government revenues in flagrant disregard to the provision of the constitution which requires that all government revenues be remitted into a single account. Many people opined of many reasons for such constituted provision to include corruption, embezzlement, 
and misappropriation of funds among others.

Nevertheless, in 2012, the Federal Government of Nigeria ran a pilot scheme for a treasury single account using 217 ministries, department and agencies (MDAs). The result showed that, Nigeria was saved of about N500 billion in frivolous spending. This report motivated the government to fully implement Treasury Single Account (TSA) and directives given to deposit money banks (DMB) to implement the technology platform that will help accommodation the Treasury Singly Account Scheme. [5] disclosed that President Mohammed Buhari directed all government revenues to be remitted to a Treasury Single Account in consonance and in compliance with the provisions of the 1999 constitution. This implies that the deposit money banks will continue to maintain revenue collection accounts for Ministries, Departments and Agencies but all monies collected by these banks will have to be remitted to the Consolidated Revenue Accounts with the CBN at the end of each banking day. In other words, Ministries, Departments and Agencies (MDAs) accounts with deposit money banks must be zerorized at the end of every banking day by a remittance to the Treasury Single Account of all revenue collected. [1] declared that the implication for the banks is that, there will no longer have access to the float provided by the accounts they maintained for the Ministries, Department and Agencies. The accounts with deposit money banks will be maintained for transaction purposes, for funds inflows and outflows of the Treasury Single Account.

Over years, Nigeria's public funds have not been properly accounted-for. To eliminate or minimize this menace, in 2015, the Federal government of Nigeria implemented TSA. Although, a state government is defined as the separate institutional unit that exercise some government functions between those of the federal government and above those units at local government level, excluding the administration of social security funds (Eurostat Glossary), the State Governments of Nigeria have been left-out of which federation government is a system, interrelated parts of other units or tiers of government; Besides, it seems that there is no study to examine the adoption and full implementation of Treasury Single Account (TSA) by State Governments of Nigeria; its benefits, challenges and prospects. Against this background, the main aim of the study is to examine the benefits of adoption of Treasury Single Account (TSA) by State Governments in Nigeria. Sub-objectives include:

i). To determine the challenges and prospects of adoption of Treasury Single Account (TSA) by the state governments.

ii). To proffer away forward towards successful implementation of Treasury Single Account (TSA) by the states governments.

\section{Research Question}

This question was raised to guide the study:

What are the benefits, challenges and prospects of adoption and full implementation of Treasury Single Account (TSA) by state government in Nigeria?

Research Hypothesis
There is no significant benefit of adoption of Treasury Single Account (TSA) by state governments of Nigeria.

\section{Review of Related Literature}

\subsection{Conceptual Framework}

[2] defined Treasury Single Account (TSA) as a unified structure of government bank accounts enabling consolidation and optimum utilization of government cash resources. In other words, a TSA is a bank account or a set of linked bank accounts through which the government transacts all its receipts and payments and gets a consolidated view of its cash position at the end of each day. It an essential tool for consolidating and managing government's cash resources, thus minimizing borrowing cost. Treasury Single Account is a public accounting system under which all government revenue, receipts and income and collected into one single account, usually maintained by the country's Central Bank and all payments done through this Account as well [6]. It is a policy or monetary tool that increases the revenue inflow in the purse of the government as well as places it in a better stead to adequately meet its financial obligations to the citizens of the country.

According to [7], TSA is a way of unifying various government's bank accounts to give a consolidated view of government cash resources. For Treasury Single Account (TSA) to work effectively there must be daily clearing of and consolidation of cash balance into the central account even where the MDA's accounts are already held at the CBN. However, this objective can be achieved through proper accounting rather than by holding cash in separate bank accounts. Treasury Single Account therefore covers all funds including votes and extra-budgetary accounts or even funds held in trust by government. To actualize, this aim, accounting system must be robust and capable of accurately distinguishing trust assets in the Treasury Singly Account (TSA).

\subsection{Theoretical Framework}

A number of different theories of socioeconomic accounting were borrowed to form sound foundation to substantiate Treasury Single Account adoption and implementation. Examples are:

Stakeholder Theory: It assumed that adoption of Treasury Single Account by the federal government is as a result of the pressure from stakeholders/citizens majorly against corruption. It suggested that the government will responds to the concerns and expectations of powerful stakeholders/citizens and some of the responses will be in the form of strategic opinions. Stakeholders' theory provides rich insights into the factors that motivate government in relation to the adoption and implementation of Treasury Single Account.

Public Finance Management Theory: This theory assumed that all aspects of financial resources - mobilization and expenditure should be well managed in government for the 
benefits of the citizenry. It includes resources mobilization, prioritization of programmes, the budgetary process, efficient management of resources and exercising control to guide against threats. Treasury Single Account (TSA) primarily is to avoid misapplication of public funds [8].

Modern Money Theory (MMT): It a theory that theorized how monetarily sovereign governments operate and their impacts on the economy. It shows that it is relevant to aggregate the central bank and the treasury into a government sector that finances itself through monetary creation such that financial position of the treasury and the central bank are so intertwined that both of them are constantly in contact in order to make fiscal and monetary policy run smoothly.

\subsection{Acts Instituted by Government to Strengthen Treasury Single Account (TSA) in Nigeria}

(i). Fiscal Responsibility Acts (2007): These are economic tools designed to enhance fiscal prudence by placing statutory obligations on federal, state and local governments to commit to transparent fiscal, budget practices and economic objectives that can be evaluated overtime [9].

(ii). CBN 2015 Guidelines for Compliance with Treasury Single Account by Banks in Nigeria.

(iii). The Constitution of Federal Republic of Nigeria, 1999 (as amended), Section 8.

\subsection{Empirical Framework}

According to [4], the benefits of a government operating a Treasury Single Account (TSA) are:

i). Allows complete and timely information on government cash resources

ii). Improves appropriation

iii). Improves operational control during budget execution

iv). Enables efficient cash management

v). Reduces bank fees and transaction costs

vi). Facilitates efficient payment mechanisms

vii). Improves bank reconciliation and quality of fiscal data viii). Lower liquidity reserve needs.

Other benefits include: TSA is a tool to combat corrupt practices, eliminate indiscipline in public and ensure adequate fund flow for economy development. Blocking of Leakages that have stunted the growth of the economy as government would have funds to invest in capital projects there stimulating various sectors of economy [10].

- Ensuring of accountability of government receipts and expenditure. The implementation of TSA is a critical step towards curbing corruption in public finance.

- Promotion of transparency, reduction of corruption and diversion of public funds, elimination of idle funds left in numerous accounts in commercial banks usually used to bear interest for corrupt entities and easier reconciliation of revenue collections and payments [11].

Nevertheless, in a short run operation of TSA will negatively impact the Nigerian Stock Exchange as a like in deposit rates would reduce returns from equities to the money market. Inflation will increase, returns on real estate investments will fall, the manufacturing sector will also be affected negatively. The rate of unemployment will increase and the banking sector will be worst hit by the TSA scheme in the short-term [1], [7], [12] and [13].

\section{Methodology}

Descriptive cross-sectional survey design was adopted. This design was considered most appropriate as it allowed seeking the views of knowledgeable individuals on certain aspects of Treasury Single Account (TSA), which provide generalized opinions/statistics from the number of individual cases. The population for the study consisted of 200 Professional Accountants in Akwa Ibom State of Nigeria as at January 31, 2016 (ICAN members and ANAN members) who served in different sectors of the economy. Taro Yamane's statistical formula was used to select sample size of 133 out of 200. Purposive sampling technique was used to select the 133 respondents/samples. This sampling technique was adopted based on the ease with which the data can be collected as well as those well versed with the knowledge of the subject matter. Data were obtained specifically from the respondents using a structured questionnaire tagged "Adoption of Treasury Single Account (TSA) by state governments of Nigeria: Benefits, Challenges and Prospects". This instrument was validated by experts and authorities in the field of government accounting. The data obtained was analyzed using descriptive statistics and t-test statistics.

\section{Data Analysis and Findings}

\subsection{Descriptive and T-test Statistics}

Data in Table 1 show that the descriptive analysis of the perception of the benefits of TSA. Result obtained shows that the respondents strongly agree that TSA ensure accountability of government revenue enhance transparency, and avoid misapplication of public funds. The result also reveals that the respondents agree on the other perceived benefits of TSA as indicated in Table 1. In overall, the weight means score of 4.20 was obtained which is above the cut-off point of 3.0 for five points rating scale. This implies that TSA was perceived to be beneficial. Table 1 also shows that accountability of government revenue, enhance transparency and avoid misapplication of public funds was the major most rated perceive benefits of full adoption and implementation of TSA by the state government.

Table 2 shows result of the analysis of the challenges confronting the adoption and implementation of TSA. As shown in Table 2, inadequate capacity in the form of access and ability to use the internet followed by its perceived negative effect on the liquidity of deposit money banks were identified as the major challenges confronting the full implementation of TSA.

Test of Hypothesis

$H o$ : there is no significant benefit of adoption and full implementation of TSA by the state governments of Nigeria. 
Table 1. Descriptive Statistics Showing Rating of the Benefits of TSA adoption and full implementation by the State Governments in Nigeria.

\begin{tabular}{|c|c|c|c|c|c|c|}
\hline $\mathbf{s} / \mathbf{n}$ & Items & $\mathbf{n}$ & $\bar{X}$ & SD & Rank & Remarks \\
\hline 1 & $\begin{array}{l}\text { Ensuring accountability and control of government revenue, enhance transparency and avoid } \\
\text { misapplication of public funds. }\end{array}$ & 133 & 4.64 & 0.48 & 1 & SA \\
\hline 2 & It gives a consolidated view of government cash/revenue at any time & 133 & 4.41 & 0.72 & 2 & A \\
\hline 3 & Effective cash management and timely information on cash resources. & 133 & 4.11 & 0.99 & 5 & A \\
\hline 4 & $\begin{array}{l}\text { It will block revenue leakages, reduces pockets of idle cash balances held as well as bank } \\
\text { transaction fees. }\end{array}$ & 133 & 3.82 & 1.09 & 8 & A \\
\hline 5 & $\begin{array}{l}\text { TSA promotes proper planning and monitoring of revenue as well as assisting to meet } \\
\text { financial obligations to the citizens. }\end{array}$ & 133 & 4.06 & 1.03 & 6 & A \\
\hline 6 & $\begin{array}{l}\text { Enable government to know how much is accruing to it on a daily basis, thus, reduces } \\
\text { corruption. }\end{array}$ & 133 & 4.39 & 0.65 & 3 & A \\
\hline 7 & Makes easier accounts auditing in government and facilitates efficient payment mechanisms. & 13 & 4.38 & 0.65 & 4 & A \\
\hline \multirow[t]{2}{*}{8} & TSA is online and in real time, as transactions could be done from anywhere in the world. & 133 & 3.95 & 1.24 & 4 & A \\
\hline & Overall & 133 & 4.20 & 0.85 & & A \\
\hline
\end{tabular}

$\mathrm{A}=$ Agree, $\mathrm{SA}=$ strongly agree

Table 2. Descriptive Statistics Challenges of Adoption and Full Implementation of TSA by the State Governments.

\begin{tabular}{|c|c|c|c|c|c|c|}
\hline $\mathbf{s} / \mathbf{n}$ & Items & $\mathbf{n}$ & $\bar{X}$ & SD & Rank & Remarks \\
\hline 1 & Inadequate capacity in the form of access and ability to use the internet to do transactions. & 133 & 4.28 & 0.68 & 1 & A \\
\hline 2 & Fear of autonomy by $\mathrm{CBN}$ on certain agencies and organisations. & 133 & 3.74 & 1.12 & 3 & A \\
\hline 3 & Commercial banks liquidity will be affected as free funds deposited will no longer be available. & 133 & 3.80 & 1.10 & 2 & A \\
\hline \multirow[t]{2}{*}{4} & $\begin{array}{l}\text { Many bank staff in-charge of public fund transactions will be retrenched, which may lead to } \\
\text { termination of employment. }\end{array}$ & 133 & 3.64 & 1.10 & 4 & A \\
\hline & Overall & 133 & 3.87 & 1.00 & & A \\
\hline
\end{tabular}

A $=$ Agree.

Table 3. Result of Test of Hypothesis on the benefits of adoption and full implementation of TSA by the State Governments in Nigeria.

\begin{tabular}{lllllll}
\hline Variable & $\mathbf{N}$ & $\overline{\boldsymbol{X}}$ & $\mathbf{S D}$ & Hypothesized mean & $\mathbf{t}_{\text {cal }}$ & Remarks \\
\hline TSA & 133 & 4.20 & 0.55 & 3.00 & 24.87 & $*$ \\
\hline
\end{tabular}

$\mathrm{df}=132 *=$ Significant, at $0.05(\mathrm{p}<0.05), \mathrm{t}_{\text {critical }}=1.98$.

Result in Table 3 shows that the calculated $t$ (24.87) is greater than the critical value of $t$ at 0.05 level of significance. Therefore, the null hypothesis is rejected. Hence, there is significant benefits of adoption and full implementation of TSA by state governments in Nigeria. This result supports the studies of [2], [3] and In summary, the result shows that 121 respondents representing 91 percent of the respondents opined that state governments in Nigeria should fully adopt and implement TSA.

\subsection{A Call for State Governments in Nigeria to Adopt and Implement TSA and How}

Evidence-based studies that examined adoption and implementation of TSA by Federal and State Governments are scare, especially in Africa. This may be due to no stringent the demand for public funds control by the countries. But Nigeria's situation now can be likening to that of India some years back. Today, India is rounded, one of the best five fastest growing economies in the whole world. What did she do? The Federal and the State Governments adopted and full implemented TSA [4].

How this can be done in Nigeria: State governments have to enter into agreement with the Central Bank of Nigeria State Branch, CBN to collate all the money remittance from all transactions daily by the deposit money banks. The TSA main account at the $\mathrm{CBN}$ must be supplemented by subsidiary ledger accounts in a correspondent service bank, deposit money bank (appointed by the state government) to record and control payments attributable to each ministry (for both revenue collection and payment disbursement). The deposit money banks having State TSA platform transaction accounts must be operated on a zero-balance basis and set-off at the end of the business daily with the respective subaccount of the TSA. A mixed of modernized centralized and decentralized design, with sub-accounts for ministries been maintained with the appointed correspondent/transaction service bank subject to CBN scrutiny. The role of deposit money banks in the TSA operations should only be revenue collection (remunerated based on the unit price per electronic transaction instead on turnover value transactions) while appointed correspondent/transaction service bank carryout disbursements and then reconciled with the $\mathrm{CBN}$.

\section{Conclusion}

The adoption of treasury single account (TSA) by State Governments of Nigeria: its benefits, challenges and prospects were examined in this study. The finding reveals that, TSA adoption and full implementation by the state governments will be of greatest benefits as showed in the weighted means scores of 4.20 and $t_{\text {cal }}$ of 24.87 ; there will be challenges in a short-run but the benefits at a long-run will definitely out-weight the challenges. It is the conclusion in this study that State Governments in Nigeria should adopt and fully implement TSA for successful control and 
accountability of public funds so as to avoid bailout funds always from any source.

\section{Recommendations}

The following recommendations are made:

1. State governments should enlighten all stakeholders on the benefits of TSA adoption.

2. There should be an integrated financial management information system (IFMIS) for all the players in the TSA system at the state levels.

3. Professional and regulatory bodies (ICAN, CBN, IMF, etc.) should help in designing, conceptualizing and road-mapping of TSA at the state level.

4. The state government accounting system should be designed to record all transactions and capture relevant information independently of the cash flows in specific bank accounts.

5. Government accountants and heads of State MDAs should be well trained to meet up with the challenges of TSA operations.

\section{References}

[1] I. Adeolu, Understanding the treasury single account (tsa) system - things you should know. Business \& Economy, Market Development.

[2] S. Pattanayak and I. Fainboim, Treasury single account: an essential tool for government cash management. Fiscal Affairs Department, IMF, August 2011.
[3] Constitution of Federal Republic of Nigeria, 1999 (as amended).

[4] S. Pattanayak and I. Fainboim, Treasury single account: concept, design and implementation. IMF Working Paper, May 2010, pp. 1-47.

[5] CBN, Revised guidelines for compliance with treasury single account by banks in Nigeria, 2015 .

[6] I. Yusuf, Counting cost of treasury single account, The Nation, September 27, 2015.

[7] T. Oyedele, Nigeria: what does the new treasury single account (TSA) hold for tax? PWC Nigeria, October 2015.

[8] J. Grubber, Public Finance and Policy. New York: Work Publications, p. 2, ISBN 7167 - 8655- 9, 2005.

[9] V. Alok, Assignment systems in federations, $5^{\text {th }}$ International Conference on Federalism Conference Reader, New Delhi, India, November 2007, pp. 107-113.

[10] O. Enwegbara, "Buhahri's tsa directive is timely" Sahara reporters. http://saharareporters.com/2015/08/12/...

[11] O. Okechukwu and D. Chukwurah, An analysis of pros and cons tsa policy in Nigeria. Arbian Journal of Business and Management Review (OMAN Chapter), 2015, vol. 5 (1), pp. 21-39.

[12] D. Adams, "CBN advises states to adopt treasury single account. Web Publication, September 2015.

[13] Systemspece, Understanding the treasury single account (tsa) system - things you should know. The Statwart Report, 2015. 